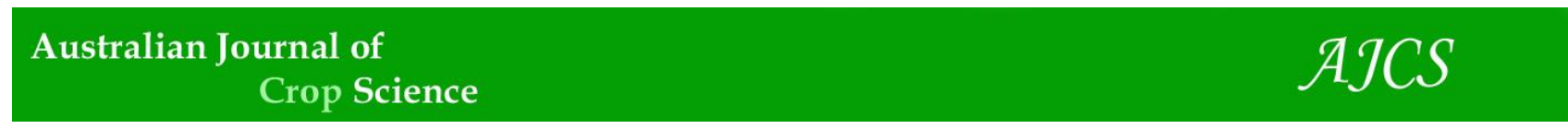

AJCS 10(8):1118-1126 (2016)

ISSN:1835-2707

DOI: 10.21475/ajcs.2016.10.08.p7596

\title{
Development of super early genotypes for the dry bean (Phaseolus vulgaris) as affected by nitrogen management
}

\author{
Adriano Stephan Nascente ${ }^{1 *}$, Alexandre Bryan Heinemann¹, Luciana Christina Alves ${ }^{2}$, Paulo Holanda \\ Rosa $^{3}$, Luis Fernando Vieira Naves ${ }^{3}$, Anne Carullyne Francino Garcia ${ }^{3}$.
}

\author{
${ }^{1}$ Brazilian Agricultural Research Corporation (EMBRAPA), Rice and Beans Research Center, PO Box 179, \\ 75375-000, Santo Antônio de Goiás, State of Goiás, Brazil \\ ${ }^{2}$ Montes Belos Faculty, 76100-000, Sao Luis de Montes Belos, State of Goiás, Brazil \\ ${ }^{3}$ UniAnhanguera University, 74423-115, Goiânia, State of Goiás, Brazil
}

*Corresponding author: adriano.nascente@embrapa.br

\begin{abstract}
The super early genotypes (SEG) of dry bean (Phaseolus vulgaris L.) have a shorter life cycle (65-75 days) when compared with the season length of traditional cultivars (90-100 days). Timing of nitrogen top-dressing fertilization could be different because of this reduction in length of the SEG life cycle. This study aimed at characterizing, by using growth analysis and vegetation index, super early genotypes of dry bean development as affected by timing of nitrogen application. Field experiments were conducted in the 2014 and 2015 growing seasons in central Brazil with a randomized block experimental design with split plots scheme and four replicates. The plots comprised the dry bean genotypes (Colibri - check cultivar, CNFC 15873, CNFC 15874, and CNFC 15875), and subplots comprised applications of $\mathrm{N}$ at different timings: $90 \mathrm{~kg}$ of $\mathrm{N}$ at sowing, $90 \mathrm{~kg} \mathrm{~N}$ at top-dressing; $45 \mathrm{~kg}$ of $\mathrm{N}$ at sowing plus $45 \mathrm{~kg}$ at top-dressing, with urea as the source of $\mathrm{N}$. We also used a control treatment without $\mathrm{N}$ application. The CNFC 15874 super early genotype of dry bean had the higher grain yield $\left(2776 \mathrm{~kg} \mathrm{ha}^{-1}\right)$ and differed from the CNFC 15873 genotype $\left(2492 \mathrm{~kg} \mathrm{ha}^{-1}\right)$. Nitrogen fertilization allowed higher grain yield $\left(2619 \mathrm{~kg} \mathrm{ha}^{-1}\right.$, when applied $\mathrm{N}$ at sowing, $2605 \mathrm{~kg} \mathrm{ha}^{-1}$, when applied $\mathrm{N}$ at sowing and at topdressing, and $2680 \mathrm{~kg} \mathrm{ha}^{-1}$, when applied $\mathrm{N}$ at top-dressing) than the control, $2360 \mathrm{~kg} \mathrm{ha}^{-1}$ (no $\mathrm{N}$ fertilization). The time of $\mathrm{N}$ fertilization in super early genotype of dry bean did not affect grain yield.
\end{abstract}

Keywords: early application of N; fertilization; Brazilian cerrado; sustainable agriculture.

Abbreviations: DAE_days after emergence; SEG_super early genotype; NDVI_normalized differential vegetation index; LAI_leaf area index; Kc_crop coefficient; AWC_available water capacity; DD_degrees day.

\section{Introduction}

The dry bean (Phaseolus vulgaris L.) crop is of significant economic importance in many countries of the world, and is considered an important source of protein for human consumption. In the 2012 harvest, 23 million $\mathrm{Mg}$ of dry bean grains were produced worldwide, and the principal producers were Myanmar (3.72 Mg), India (3.63 Mg), Brazil (2.82 Mg), China $(1.45 \mathrm{Mg})$, the USA $(1.44 \mathrm{Mg})$, and Mexico $(1.08 \mathrm{Mg})$ (FAOSTAT, 2014). However, despite its importance, technology is seldom used for dry bean farmers, resulting in a global average grain yield of only $804 \mathrm{~kg} \mathrm{ha}^{-1}$ (FAOSTAT, 2014). The use of super early genotypes (SEG) of dry bean would allow achieving high grain yields in a shortest time, thus providing irrigation water and power savings and hence reducing the cost of production. This technology would also allow best land use, such as cultivation of two crops during the rainy season, or even up to three crops during the same year in irrigated areas. For rainfed season, the SEG can allow to escape from drought periods when late sowing. Besides, the use of SEG would provide the reduction in costs and production risks, since the cultivar with shortest cycle provides the most rapid withdrawal of the crop from the field. Therefore, the crop becomes less subject to attacks of insects, diseases, and weeds. To produce more food and in a shortest time is very important for many developing countries, such as the Americas and Eastern and Southern Africa, which use the grain of this crop in their daily human diets (Rosales-Serna et al., 2004; Lima et al., 2005). The Brazilian Agricultural Research Corporation (Embrapa), by the National Rice and Beans research Center, has developed new genotypes of dry beans with super early cycle. These genotypes have life cycles of 65-75 days, compared with life cycles of 90-100 days for traditional cultivars. This reduction in length of the life cycle could mean that there is insufficient time for uptake of nitrogen $(\mathrm{N})$ if it is applied at the same time as those for the traditional cultivars. However, there is not any study about the nitrogen management in the SEG of dry bean. It is important to establish sources, amounts, and time of nitrogen fertilization in these genotypes to have more efficient use of this nutrient (Malavolta, 2006; Fageria et al., 2011; Pagani and Mallarino, 2012; Crusciol et al., 2013a).

Growth analysis allows determining the allocation of photosynthate partition as a function of the age of the plant, and could be an important tool to evaluate the development of these new genotypes. The determination of dry matter accumulation (plant and its parts: stems, leaves, and pods) is the most suitable tool for the growth analysis (Rosales-Serna 
et al., 2004; Andrade et al., 2009; Santos et al., 2015). This growth analysis can be used to verify the crop adaptation to new environments, interspecific competition, effects of the management system, and yield potential of different genotypes (Antoniazzi and Deschamps, 2006; Falqueto et al., 2009; Alvarez et al., 2012).

Therefore, this study aimed at characterizing, by using growth analysis and vegetation index, super early genotypes of dry bean development as affected by timing of nitrogen application.

\section{Results}

\section{Common bean grain yield and biomass accumulation}

The application of nitrogen at sowing, topdressing or split at sowing, and topdressing allowed increase in grain yield and differed from the treatment with no nitrogen application (Table 2). There was no single effect of $\mathrm{N}$ top-dressing fertilization and interactions for the variables evaluated at the harvesting time. On the other hand, there were single effects of genotypes (stems, leaves, total, and grain yield) and growing seasons (pods, total, and grain yield). Then, in the 2014 growing season, dry biomass accumulated was higher in pods $\left(156 \mathrm{~g} \mathrm{~m}^{-1}\right)$, total $\left(208 \mathrm{~g} \mathrm{~m}^{-1}\right)$, and grain yield (3098 $\left.\mathrm{kg} \mathrm{ha}^{-1}\right)$ than in pods $\left(81 \mathrm{~g} \mathrm{~m}^{-1}\right)$, total $\left(140 \mathrm{~g} \mathrm{~m}^{-1}\right)$, and grain yield $\left(2172 \mathrm{~kg} \mathrm{ha}^{-1}\right)$ in the 2015 growing season.

The CNFC 15875 genotype had the lowest values and differed from the CNFC 15874 in stems, leaves, pods, and total dry biomass accumulated (Table 2). CNFC 15874 genotype did not differ from Colibri (check cultivar) and CNFC 15873 for the variables stems, leaves, and total dry biomass at harvesting time. CNFC 15873 had lower dry biomass of pods and differed from CNFC 15874. Regarding grain yield, CNFC $15874\left(2776 \mathrm{~kg} \mathrm{ha}^{-1}\right)$ had the highest value and differed from CNFC $15873\left(2492 \mathrm{~kg} \mathrm{ha}^{-1}\right)$.

\section{Nitrogen fertilization and genotypes affecting growth analysis}

It was found that, regardless of genotype and growing season, the curve that best adjusted to the total dry mass accumulation was the quadratic exponential (Figs. 2 and 3). In 2014, the dry bean plants had a longer cycle, and samples were made until 77 days after emergence, DAE (912.5 degree-days, DD. At this growing season, in the early plant development (21 DAE), the accumulation of total biomass was not very expressive (ranging between genotypes from 11.04 to $\left.15.00 \mathrm{~g} \mathrm{~m}^{-1}\right)$, increasing to the beginning of grain filling (ranging from 65.01 to $85.46 \mathrm{~g} \mathrm{~m}^{-1}$ ). From the grain filling stage until near the maturation stage, there was a large increase in biomass pod (starting from 0.26 to $5.64 \mathrm{~g} \mathrm{~m}^{-1}$ at $42 \mathrm{DAE}$, and from 144.08 to $165.53 \mathrm{~g} \mathrm{~m}^{-1}$ at $\left.77 \mathrm{DAE}\right)$. On the other hand, the accumulation of dry matter of stems was increased until 56 DAE in all genotypes and leaves biomass between 42 and 56 DAE. The Colibri $\left(217.80 \mathrm{~g} \mathrm{~m}^{-1}\right)$ and CNFC 15874 (229.35 $\mathrm{g} \mathrm{m}^{-1}$ ) genotypes had higher total dry biomass accumulation throughout the cycle.

In the 2015 season, the plants had lower life cycle length than the previous growing season, and the plant samples for growing analyses were done until 70 DAE or 849.9 DD (Fig. 3 ). At this growing season, it was found accumulations of dry biomass in the stems and leaves up to $49 \mathrm{DAE}$, when values began to decrease, and in the pods from the grain filling stage, the values were increasing until harvest. The CNFC 15874 genotype was the one that presented the highest dry biomass accumulation of values in stems, pods, and total during the life cycle of dry bean.

The time of the nitrogen fertilizer significantly affected the development of genotypes (Figs. 4 and 5). In the 2014 season, the nitrogen fertilization split $50 \%$ at sowing, and $50 \%$ at topdressing provided the highest values for biomass accumulated of stems, pods and total dry matter. In the 2015 season, the $\mathrm{N}$ management that provided the higher values for biomass accumulated of stems, pods, and total dry matter was when occurred the application of the whole $\mathrm{N}$ at sowing and when split $50 \%$ at sowing and $50 \%$ at topdressing (Fig. 5).

\section{Nitrogen fertilization and genotypes affecting NDVI}

Crop reflectance readings during the 2014 growing season showed that when there was no $\mathrm{N}$ application, highest values for all genotypes were reached at 39 DAE (Fig. 6). All genotypes showed the same trend, being the highest NDVI value at $39 \mathrm{DAE}$. There was no difference among treatments, even $0 \mathrm{~N}$ treatment showed the same trend. For all treatments, the CNFC 15875 genotype showed the lowest NDVI values after flowering.

\section{Nitrogen fertilization and genotypes affecting LAI}

Regarding the leaf area index (LAI) values for all genotypes and for all $\mathrm{N}$ management, we could see that in the early development of the dry bean plants values were low and increased until 35-49 DAE (Fig 8). The treatment that showed the highest LAI value was $\mathrm{N}$ at topdressing for CNFC 15875 genotype (Fig. 9).

\section{Discussion}

\section{Crop length season}

Crop length season for all genotypes was greater in the 2014 growing season due to the lower temperature during the vegetative stage of common bean development in the same year (Fig. 1). According to Vieira et al. (2006), low temperatures increase the life cycle of common bean genotypes. As a consequence, they allow higher biomass accumulation (Figs. 2 and 3) and grain yield (Table 2) (Crusciol et al. 2012, 2013b).

\section{Nitrogen application timing}

The application of $\mathrm{N}$ provided differences in dry bean grain yields from the control treatment (no $\mathrm{N}$ application). Nitrogen is a nutrient that directly affects the grain yield of many crops, such as dry bean (Fageria, 2014). Therefore, the lack of $\mathrm{N}$ application in the control treatment significantly affected crop development and reduced its yield. Also corroborating this information, Alvarez et al. (2005), Valderrama et al. (2009), and Nascente et al. (2012) reported a reduction in dry bean yield due to the lack of $\mathrm{N}$ topdressing fertilization.

\section{Nitrogen application timing}

Regarding nitrogen application time, differences were not observed among treatments for all variables (Table 2). Similar results were reported by Alvarez et al. (2005) and Nascente et al. (2012). Thus, the application of the total $\mathrm{N}$ at sowing, or at topdressing, or a combination of these two periods provided increments in grain yield for super early cycle. Therefore, it can be inferred that the $\mathrm{N}$ application time 
Table 1. Chemical soil attributes from the experimental area before the beginning of the trials. Santo Antônio de Goiás, Goiás, Brazil, growing seasons 2014 and 2015.

\begin{tabular}{|c|c|c|c|c|c|c|}
\hline \multicolumn{7}{|c|}{ Growing season 2014} \\
\hline Layer & $\mathrm{pH}$ & $\mathrm{Ca}$ & $\mathrm{Mg}$ & $\mathrm{Al}$ & $\mathrm{H}+\mathrm{Al}$ & SOM§ \\
\hline $\mathrm{cm}$ & in $\mathrm{H}_{2} \mathrm{O}$ & $\mathrm{mmol}_{\mathrm{c}} \mathrm{dm}^{-3}$ & & & & $\mathrm{~g} \mathrm{~kg}^{-1}$ \\
\hline $0-5$ & 6.2 & 18 & 14 & 0 & 38 & 28.0 \\
\hline 5 a 10 & 5.9 & 17 & 10 & 0 & 26 & 24.8 \\
\hline 10 a 20 & 5.7 & 11 & 7 & 1 & 23 & 27.8 \\
\hline Layer & $\mathrm{P}$ & $\mathrm{K}$ & $\mathrm{Cu}$ & $\mathrm{Zn}$ & $\mathrm{Fe}$ & $\mathrm{Mn}$ \\
\hline $\mathrm{cm}$ & $\mathrm{mg} \mathrm{dm}^{-3}$ & & & & & \\
\hline $0-5$ & 12.6 & 265 & 0.9 & 10.7 & 17.7 & 9.8 \\
\hline 5 a 10 & 18.7 & 125 & 1.5 & 8.1 & 29.5 & 8.0 \\
\hline 10 a 20 & 12.4 & 87 & 1.6 & 4.9 & 29.6 & 7.0 \\
\hline \multicolumn{7}{|c|}{ Growing season 2015} \\
\hline Layer & $\mathrm{pH}$ & $\mathrm{Ca}$ & $\mathrm{Mg}$ & $\mathrm{Al}$ & $\mathrm{H}+\mathrm{Al}$ & SOM \\
\hline $\mathrm{cm}$ & in $\mathrm{H}_{2} \mathrm{O}$ & $\mathrm{mmol}_{\mathrm{c}} \mathrm{dm}^{-3}$ & & & & $\mathrm{~g} \mathrm{~kg}^{-1}$ \\
\hline $0-5$ & 6.2 & 22.6 & 13.2 & 0 & 36 & 26.80 \\
\hline 5 a 10 & 5.7 & 6.1 & 3.9 & 3 & 33 & 23.35 \\
\hline 10 a 20 & 5.5 & 5.8 & 3.5 & 2 & 24 & 20.83 \\
\hline Layer & $\mathrm{P}$ & $\mathrm{K}$ & $\mathrm{Cu}$ & $\mathrm{Zn}$ & $\mathrm{Fe}$ & $\mathrm{Mn}$ \\
\hline $\mathrm{cm}$ & $\mathrm{mg} \mathrm{dm}^{-3}$ & & & & & \\
\hline $0-5$ & 22.5 & 139.0 & 1.5 & 4.4 & 38.2 & 9.0 \\
\hline 5 a 10 & 38.5 & 48.0 & 1.8 & 2.1 & 37.0 & 3.5 \\
\hline 10 a 20 & 13.0 & 45.0 & 1.7 & 1.9 & 27.3 & 3.7 \\
\hline
\end{tabular}

Table 2. Stems, leaves, pods and total plant dry biomass accumulated at 77 days after emergence (DAE) in growing season 2014 and at 70 DAE in growing season 2015 of super early cultivar of dry bean as a function of the nitrogen timing of genotypes (plot), top-dressing fertilization (subplots) and growing season (sub subplot), Santo Antônio de Goiás, growing seasons 2014 and 2015.

\begin{tabular}{|c|c|c|c|c|c|}
\hline \multirow[b]{2}{*}{$\underline{\text { Genotypes }}$} & \multicolumn{4}{|c|}{ Plant dry biomass } & \multirow{2}{*}{ Grain yield } \\
\hline & Stems & Leaves & Pods & Total & \\
\hline & \multicolumn{4}{|c|}{$\mathrm{g} \mathrm{m}^{-1}$} & $\mathrm{~kg} \mathrm{ha}^{-1}$ \\
\hline Colibri & $32.25 \mathrm{a}$ & $27.99 \mathrm{a}$ & 116 & $177 \mathrm{ab}$ & $2736 \mathrm{ab}$ \\
\hline CNFC 15873 & $32.83 \mathrm{a}$ & $24.45 \mathrm{a}$ & 110 & $168 \mathrm{~b}$ & 2492 b \\
\hline CNFC 15874 & $36.75 \mathrm{a}$ & $25.64 \mathrm{a}$ & 132 & $195 \mathrm{a}$ & $2776 \mathrm{a}$ \\
\hline CNFC 15875 & $24.39 \mathrm{~b}$ & $15.70 \mathrm{~b}$ & 117 & $156 \mathrm{~b}$ & $2535 \mathrm{ab}$ \\
\hline \multicolumn{6}{|l|}{$\mathrm{N}$ top-dressing fertilization } \\
\hline $90 \mathrm{~kg} \mathrm{~N}$ at sowing (S) & 31.80 & 24.03 & 117 & 173 & $2619^{+}$ \\
\hline $45 \mathrm{~kg} \mathrm{~N}$ at $\mathrm{S}$ and $45 \mathrm{~kg} \mathrm{~N}$ at $\mathrm{T}$ & $32.26^{+}$ & 23.22 & 127 & 183 & $2605^{+}$ \\
\hline $90 \mathrm{~kg} \mathrm{~N}$ at topdressing $(\mathrm{T})$ & 30.61 & 23.09 & 112 & 166 & $2680^{+}$ \\
\hline Control - 0 Nitrogen & 26.94 & 20.02 & 108 & 155 & 2360 \\
\hline \multicolumn{6}{|l|}{ Growing season } \\
\hline 2014 & 29.94 & 21.72 & $156 \mathrm{a}$ & $208 \mathrm{a}$ & 3098 a \\
\hline 2015 & 33.17 & 25.17 & $81 \mathrm{~b}$ & $140 \mathrm{~b}$ & $2172 b$ \\
\hline Factors & \multicolumn{5}{|c|}{ Analyze of variance ( $\mathrm{F}$ probability) } \\
\hline 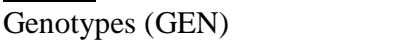 & 0.0026 & 0.0030 & 0.2594 & 0.0478 & 0.0473 \\
\hline $\mathrm{N}$ top-dressing fertilization $(\mathrm{N})$ & 0.7647 & 0.8711 & 0.2904 & 0.3968 & 0.7857 \\
\hline $\mathrm{GEN} * \mathrm{~N}$ & 0.2710 & 0.2522 & 0.6169 & 0.3891 & 0.0558 \\
\hline Growing season (GS) & 0.0720 & 0.0594 & $<0.001$ & $<0.001$ & $<0.001$ \\
\hline $\mathrm{N} * \mathrm{GS}$ & 0.6367 & 0.2572 & 0.3210 & 0.2708 & 0.7211 \\
\hline GEN * GS & 0.4744 & 0.0777 & 0.7770 & 0.6743 & 0.0949 \\
\hline $\mathrm{N} * \mathrm{GEN} * \mathrm{GS}$ & 0.7112 & 0.7489 & 0.3917 & 0.4682 & 0.1684 \\
\hline
\end{tabular}

§Means followed by ${ }^{+}$differ from the control treatment (no $\mathrm{N}$ fertilization) by the Dunnett Test at $\mathrm{p} \leq 0.05$.

$\S \S$ Means followed by the same letter vertically do not differ by the Tukey test at $\mathrm{p} \leq 0.05$. 

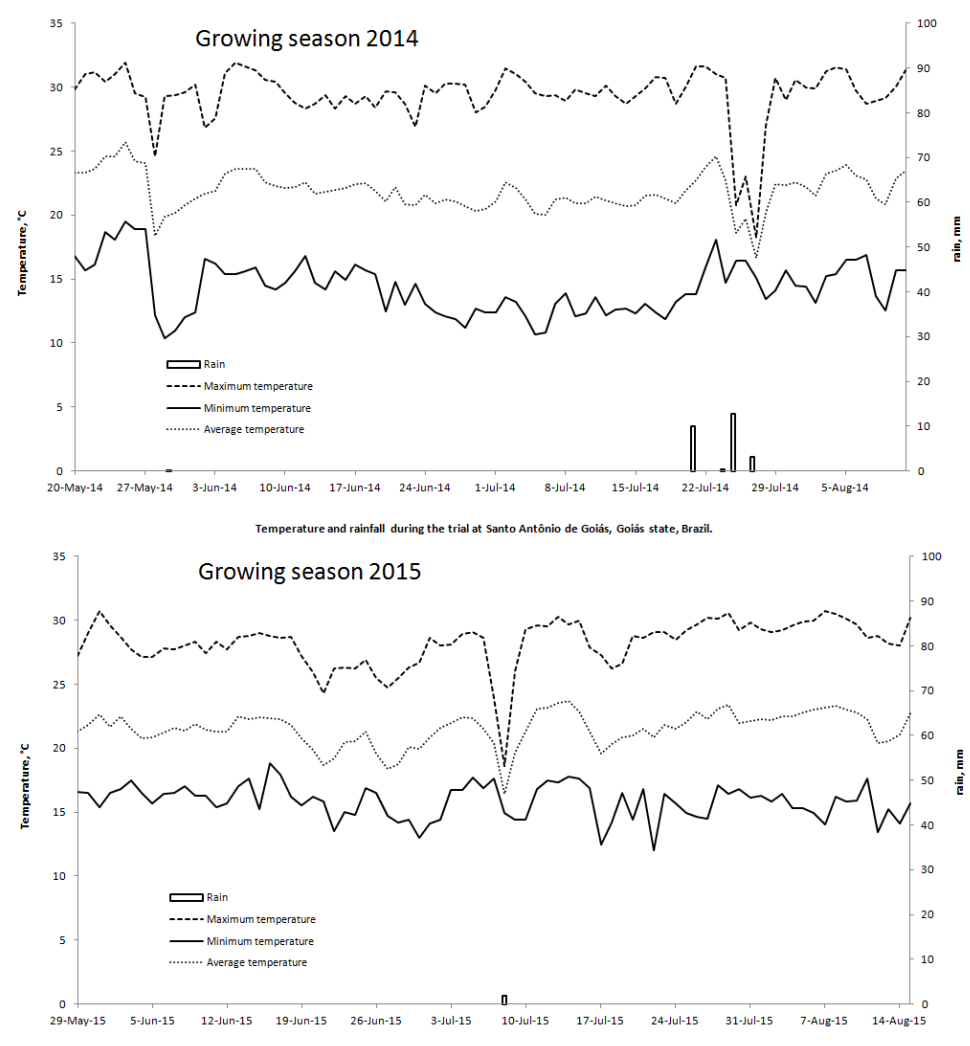

Fig 1. Maximum, minimum and average temperatures and rainfall during the trial period of super early genotypes of dry bean in the experimental fields, growing seasons 2014 and 2015.
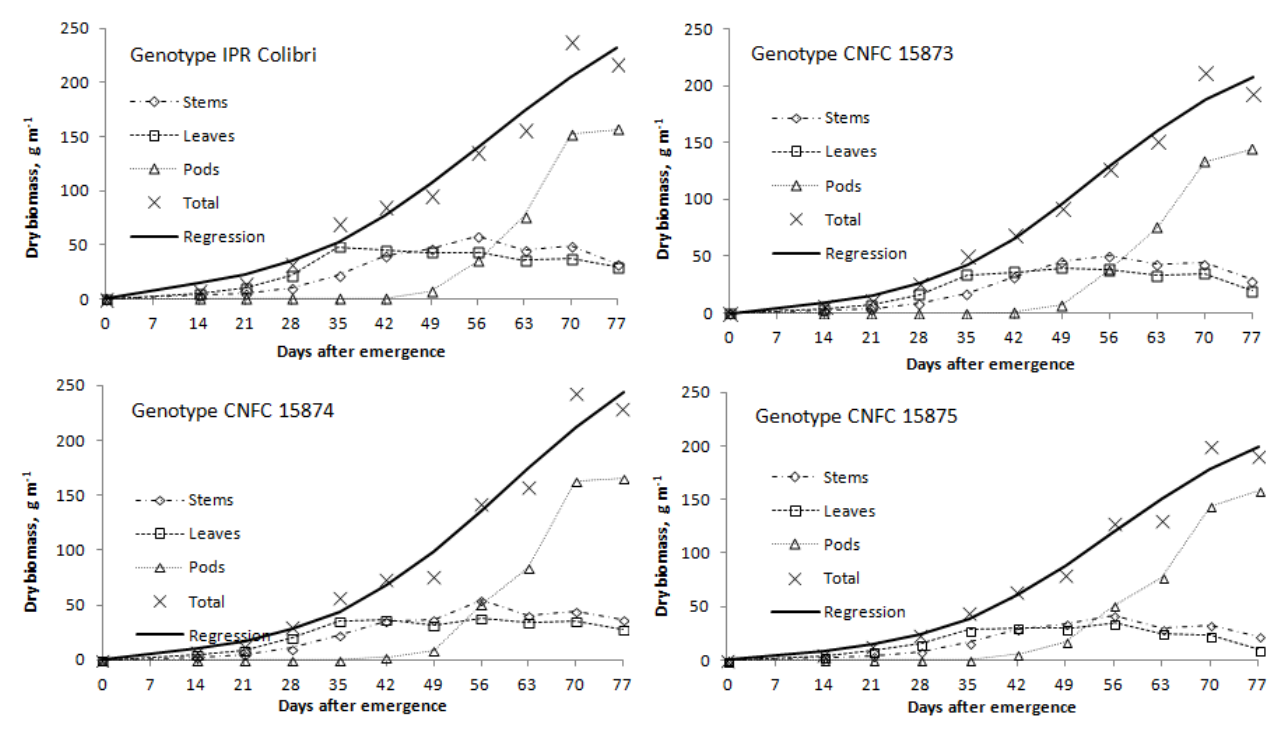

Fig 2. Stems, leaves, pods and total dry biomass accumulation during the crop life cycle of four super early genotypes of dry bean. Santo Antonio de Goiás, GO, Brazil. Growing season 2014.

does not affect the grain yield of dry bean of SEG. These results may reflect the shorter life cycle of the genotypes used. While the topdressing for traditional cultivars (life cycle of 90-95 days) is recommended for 20-25 days after emergence (Vieira et al., 2006), the super early genotypes with a life cycle of 60-65 days seem to need $\mathrm{N}$ sooner. Therefore, the application of all $\mathrm{N}$ on the day of sowing, or 15-16 DAE (time that the plant had the third trifoliate leaf and topdressing was made), or divided in these two seasons, did not affect the crop yield.The dry bean SEG CNFC 15874 $\left(2776 \mathrm{~kg} \mathrm{ha}^{-1}\right)$ did not have different values of grain yield from the cultivar used as a standard (Colibri, $2736 \mathrm{~kg} \mathrm{ha}^{-1}$ ). Based on the results, it seems that the SEG CNFC 15874 is very promising to be used primarily in the irrigated growing season, since the Brazilian average yield is $2,480 \mathrm{~kg} \mathrm{ha}^{-1}$ (Nascente et al., 2012). 

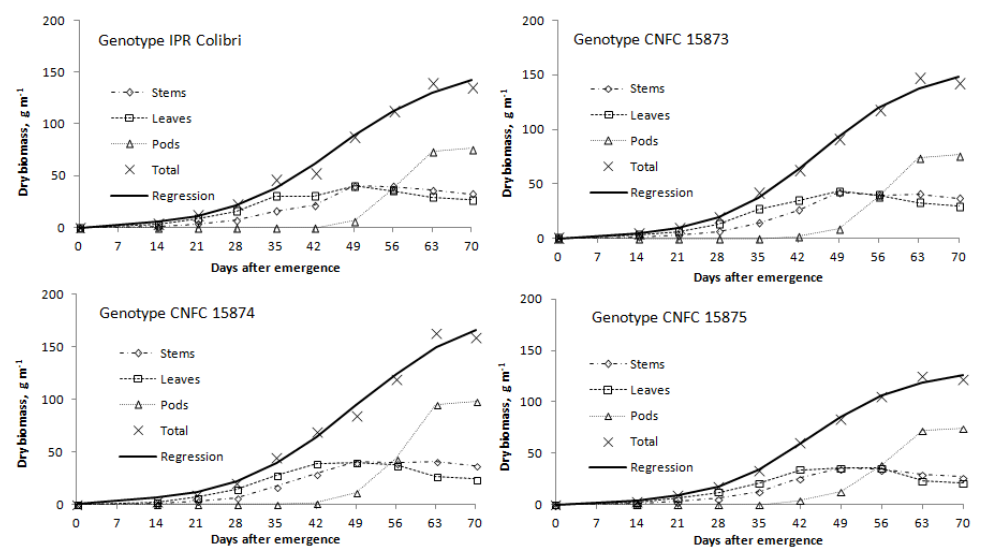

Fig 3. Stems, leaves, pods and total dry biomass accumulation during the crop life cycle of four super early genotypes of dry bean. Santo Antonio de Goiás, GO, Brazil. Growing season 2015.

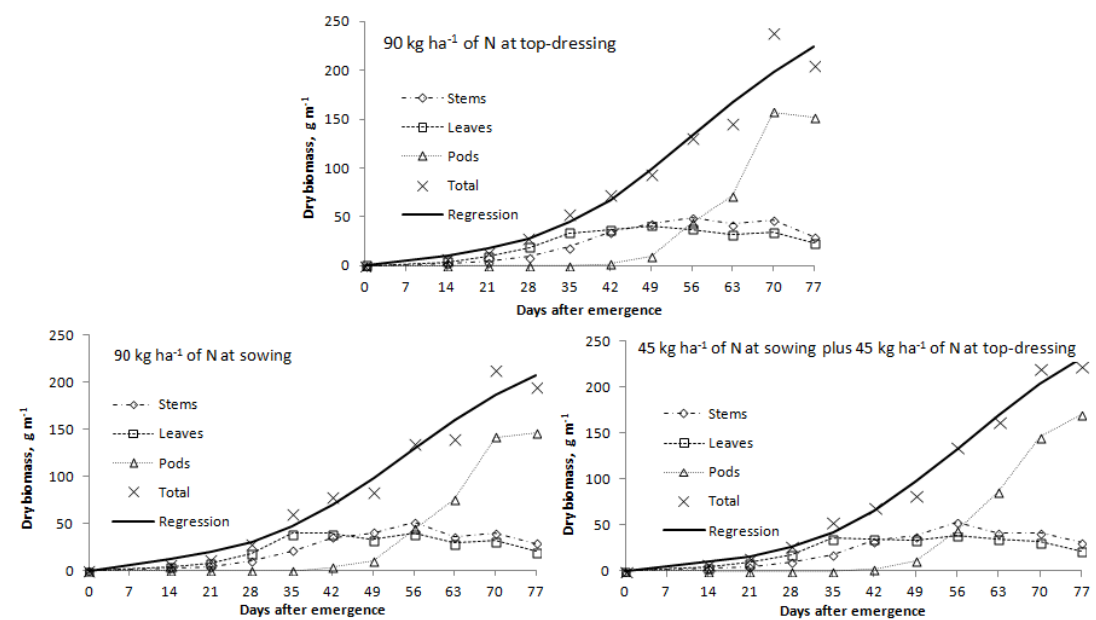

Fig 4. Stems, leaves, pods and total dry biomass accumulation during the crop life cycle of super early genotypes of dry bean as a function of nitrogen management. Santo Antonio de Goiás, GO, Brazil. Growing season 2014.

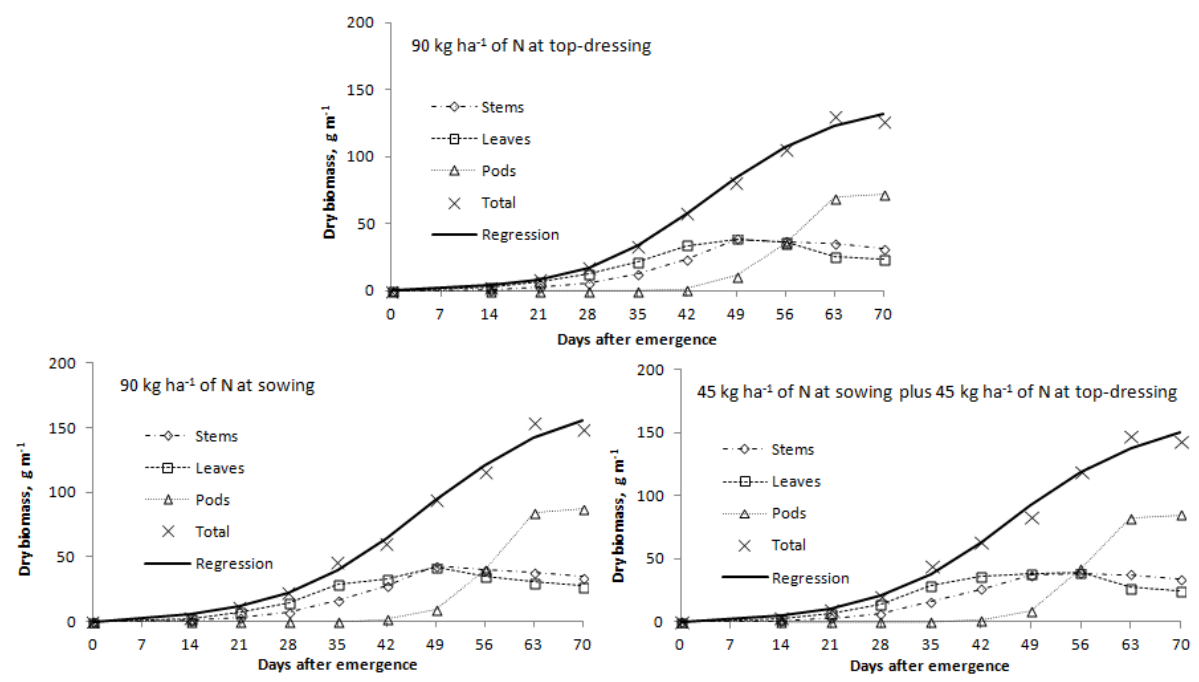

Fig 5. Stems, leaves, pods and total dry biomass accumulation during the crop life cycle of super early genotypes of dry bean as a function of nitrogen management. Santo Antonio de Goiás, GO, Brazil. Growing season 2015. 

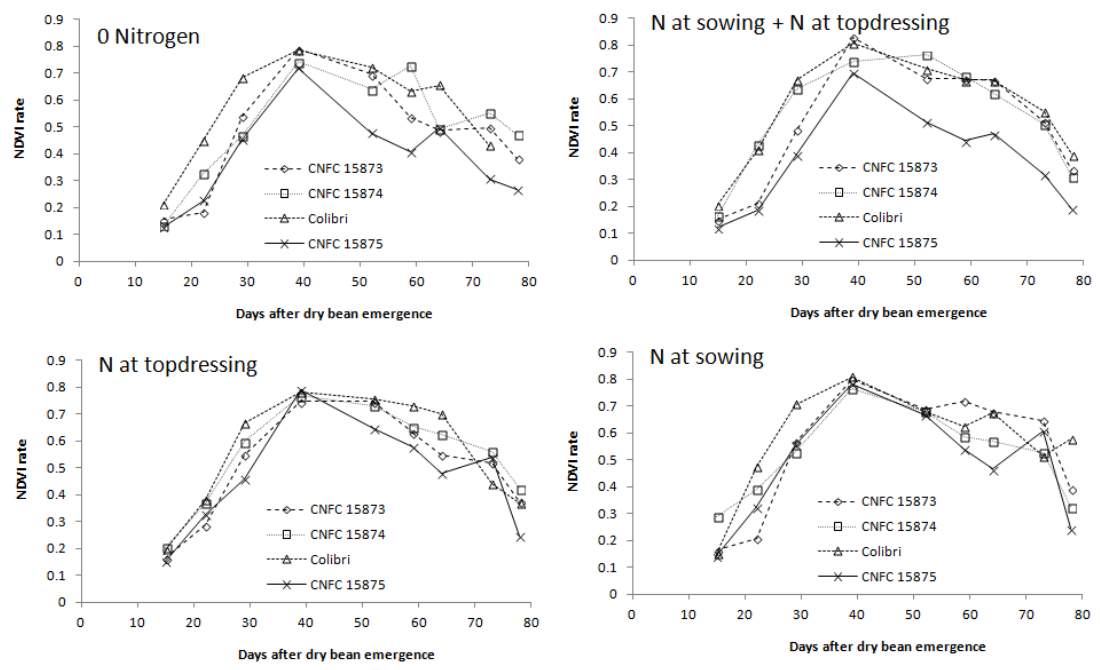

Fig 6. NDVI index during the crop life cycle of super early genotypes of dry bean as a function of nitrogen management. Santo Antonio de Goiás, GO, Brazil. Growing season 2014.
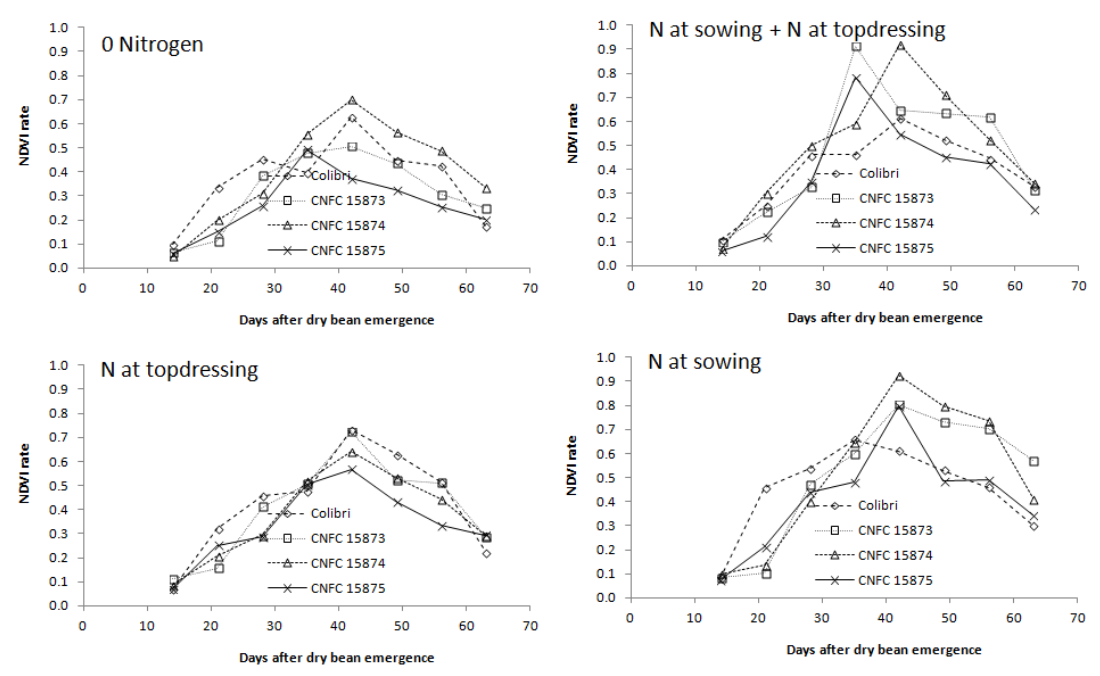

Fig 7. NDVI index during the crop life cycle of super early genotypes of dry bean as a function of nitrogen management. Santo Antonio de Goiás, GO, Brazil. Growing season 2015.
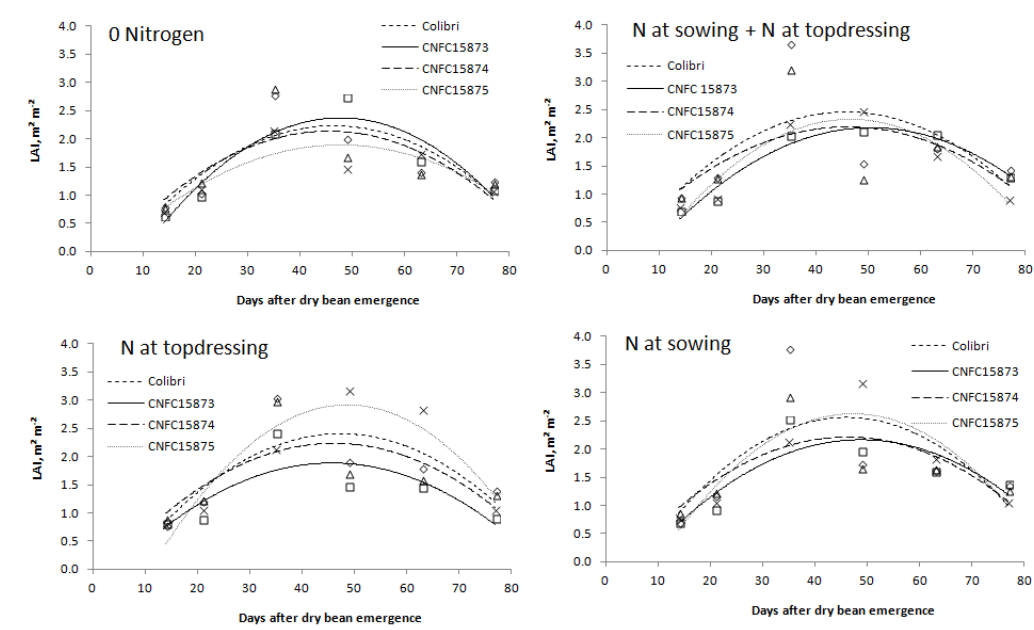

Fig 8. Leaf area index (LAI) during the crop life cycle of super early genotypes of dry beans as a function of nitrogen management. Santo Antonio de Goiás, GO, Brazil. Growing season 2014. 

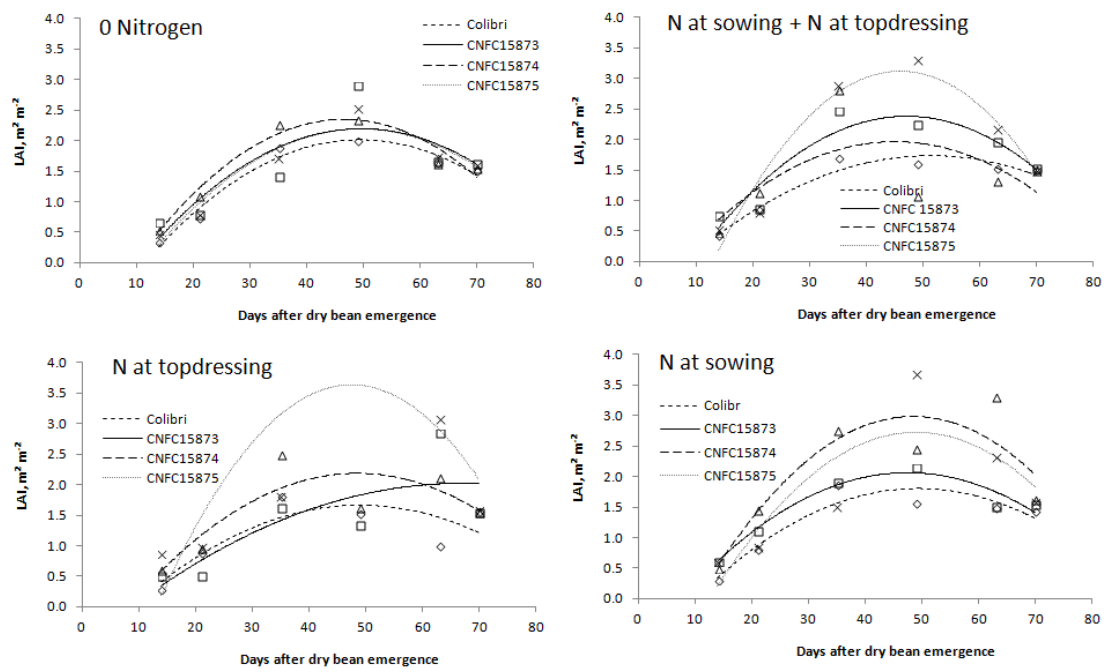

Fig 9. Leaf area index (LAI) during the crop life cycle of super early genotypes of dry bean as a function of nitrogen management. Santo Antonio de Goiás, GO, Brazil. Growing season 2015.

\section{Leaf area index and NDVI as affected by cultivars and nitrogen timming}

Leaf area index and NDVI showed similar trends. Plants of dry bean started to produce more leaves with higher values in the flowering stage (Figs. 2 and 3). Consequently, the NDVI (Figs. 6 and 7) and LAI (Figs. 8 and 9) increased as well. According to Rosales-Serna (2004), who evaluated four dry bean genotypes, the higher rate of biomass accumulation in shoots (leaves and stems) of this crop occurs during vegetative stage and during the flowering stage, but before seed filling. Because of the increase in leave biomass, an increase in LAI is likely to occur, and as leaves have many stomachs, it is also likely that the NDVI values increase, as we observed in our trials. After this period, the leave biomass started to reduce, as we could observe in the growth analysis (Figs. 2 and 3), and as the LAI and NDVI are influenced by these leaves, their values started to reduce as well. This reduction in the dry matter of the leaves started indicating that there was translocation from their photoassimilates to the pods. On the other hand, after $35 \mathrm{DAE}$, the dry mass of pods started increasing, and this could be observed in the evaluations performed at 41 and 56 DAE. According to Wien et al. (1976), in the phases of formation and filling of seeds, about $45 \%$ of photoassimilates in the leaves and stems are translocated into the pods and seeds.

Colibri, CNFC 15873, and CNFC 15874 had the same biomass accumulation for stems and leaves (Table 2). However, CNFC 15873 had not the same characteristic and ability to translocate photoassimilates to the pods, and provided higher grain yield, since this grain yield was lower than CNFC 15874. On the other hand, CNFC 15875, although had lower biomass of stems, leaves, and total, was more efficient to translocate photoassimilates to the pods, and have values of grain yield similar to Colibri and CNFC 15874 .

There are no differences for LAI and NDVI according to the $\mathrm{N}$ management, even for the control (no $\mathrm{N}$ fertilization). This could be because of the level of soil organic matter in the crop areas (Table 1), which was, in the layer 0-0.05 m, 2.8 and $2.68 \mathrm{~g} \mathrm{~kg}^{-1}$ in the 2014 and 2015 growing seasons, respectively;. These values are considered high (Sousa and Lobato, 2003). According to Fageria (2014), soil organic matter releases nitrogen into the soil, which could be uptake by the crops. In this sense, it is likely that plants did not suffer deficiency of Nitrogen, which could be seen in the NDVI values. However, the little differences in the NDVI values from the treatments with $\mathrm{N}$ against treatment control (no $\mathrm{N}$ fertilization) could help to explain the higher grain yield in these treatments (with $\mathrm{N}$ fertilization). Shaver et al. (2010) related increased NDVI values with increased rate of $\mathrm{N}$.

\section{Materials and Methods}

\section{Site description}

The field experiments were conducted for two growing seasons (2014 and 2015) at Capivara Farm, located in the city of Santo Antonio de Goias, GO, Central Region of Brazil. The geographical coordinates of the site are $16^{\circ} 28^{\prime} 00^{\prime \prime} \mathrm{S}$, $49^{\circ} 17^{\prime} 00^{\prime \prime}$ West. The altitude of the site is $823 \mathrm{~m}$. The climate is tropical savanna, considered Aw according to the Köppen classification. There are two well-defined seasons: usually, the dry season extends from May to September (autumn/winter) and the rainy season from October to April (spring/summer). Furthermore, the daily average temperature and precipitation during the experiment were monitored (Fig. $1)$.

The soil was classified as a clay loam (kaolinitic, thermic Typic Haplorthox) acidic soil. Prior to each experiment, chemical characteristics of the soil were determined (Table 1). The soil analysis was performed according to Claessen (1997). The soil $\mathrm{pH}$ was determined in a $0.01 \mathrm{~mol} \mathrm{~L}{ }^{-1} \mathrm{CaCl}_{2}$ suspension (1:2.5 soil/solution). Exchangeable $\mathrm{Ca}, \mathrm{Mg}$, and Al were extracted with neutral $1 \mathrm{~mol} \mathrm{~L}^{-1} \mathrm{KCl}$ in a $1: 10$ soil/solution ratio and determined by titration with a 0.025 mol $\mathrm{L}^{-1} \mathrm{NaOH}$ solution. Phosphorus and exchangeable $\mathrm{K}$ were extracted with a Mehlich 1 extracting solution $(0.05 \mathrm{M}$ $\mathrm{HCl}$ in $0.0125 \mathrm{M} \mathrm{H}_{2} \mathrm{SO}_{4}$ ). The extracts were calorimetrically analyzed for $\mathrm{P}$, and flame photometry was used to analyze $\mathrm{K}$. Soil $\mathrm{S}\left(\mathrm{SO}_{4}^{-2}\right)$ analyses were performed by calcium phosphate extraction at $0.01 \mathrm{~mol} \mathrm{~L}^{-1}$ in a $1: 2.5$ soil/solution ratio, and later determined by the turbidimetric method using $\mathrm{BaSO}_{4}$. Micronutrients $(\mathrm{Fe}, \mathrm{Zn}, \mathrm{Cu}$ and $\mathrm{Mn}$ ) were determined in Mehlich 1 extract by atomic absorption, and organic matter was determined by the method of Walkley and Black. 
The experimental area has been cultivated in a no-tillage system (NTS) for seven consecutive years. The last crop rotation were soybean (spring/summer), followed by corn Zea mays L. (summer), and the dry bean (autumn/winter) for the two trials. The dry biomass of corn on the soil surface at dry bean sowing was $3 \mathrm{Mg} \mathrm{ha}^{-1}$ at 2014 growing season, and $12 \mathrm{Mg} \mathrm{ha}^{-1}$ at 2015 growing season.

\section{Experimental design and treatments}

The experimental design was a randomized complete blocks layout arranged with split plots scheme and four replicates in the two growing seasons (2014 and 2015). The main plots comprised the dry bean genotypes (Colibri - control, CNFC 15873, CNFC 15874, and CNFC 15875), and subplots were applications of $\mathrm{N}$ at different timings $(90 \mathrm{~kg}$ of $\mathrm{N}$ at sowing, $90 \mathrm{~kg} \mathrm{~N}$ at top-dressing; $45 \mathrm{~kg}$ of $\mathrm{N}$ at sowing plus $45 \mathrm{~kg}$ at top-dressing), with urea as the source of $\mathrm{N}$. We also included a control treatment without $\mathrm{N}$ fertilization. Top-dressing fertilization was done at $\mathrm{V}_{4}$ phenological stage (third trifoliate leaf). The main plots consisted of 10 third twometer-long rows, spaced $0.40 \mathrm{~m}$ apart. The subplots consisted of 10 eight-meter-long rows, spaced $0.40 \mathrm{~m}$ apart. The useful area of each subplot was formed by the six central meters of the four central rows.

\section{Dry bean management}

Approximately 15 days before sowing, the experimental area was desiccated with glyphosate $+2,4 \mathrm{D}$. The base fertilization, to be applied in the sowing furrows, was calculated according to the soil's chemical characteristics and the recommendations of Sousa and Lobato (2003). The fertilizer applied at sowing consisted of $105 \mathrm{~kg} \mathrm{ha}^{-1}$ of $\mathrm{P}_{2} \mathrm{O}_{5}$ (triple superphosphate) and $52.5 \mathrm{~kg} \mathrm{ha}^{-1}$ of $\mathrm{K}_{2} \mathrm{O}$ (potassium chloride). Nitrogen fertilization was done only at top-dressing and according to each treatment.

The sowing of the dry bean cultivars was mechanically performed with a no-till seeding (Semeato, model Personale Drill 13, Passo Fundo, RS, Brazil) on May $20^{\text {th }}, 2014$ and May $29^{\text {th }}, 2015$ in a $0.40 \mathrm{~m}$ row spacing and with 15 seeds per meter. Cultural practices were performed according to the recommendations for the crop to keep the area free of weeds, diseases, and insects.

A central pivot irrigation system was used. In the management of water, three crop coefficients $(\mathrm{Kc})$ were used, divided into four periods between emergence and harvest. In the vegetative stage, the value of 0.4 was used. For the reproductive phase were used two values of $\mathrm{Kc}$, the initial value of 0.7 and the final one of 1.0 , and in the final phase of maturation these values were reversed, i.e., initial 1.0 and final 0.7. Thus, the control of irrigation considering the depth of root system exploitation of $0.2 \mathrm{~m}$ was initiated with the available water capacity (AWC) at its maximum, subtracting, successively, the value of crop evapotranspiration until the total water reached the minimum limit of $40 \%$ of AWC (Doorenbos and Pruitt, 1976).

Seedling emergence occurred at six (2014) and eight (2015) days after sowing. The average of $\mathrm{V}_{4}$ stage was at 16 and 15 days after emergence (DAE) in the 2014 and 2015 growing seasons, respectively. The average of full flowering stage was at 42 and 39 DAE in the 2014 and 2015 growing seasons, respectively. The dates have been translated into number of degree-days (DD), from sowing to full flowering. For this, we used the formula $\mathrm{DD}=$ average daily temperature - basal temperature $\left(10^{\circ} \mathrm{C}\right)$, as standard for calculation (McMaster and Wilhelm, 1997). The average growing season (length of time from emergence to harvest) was 77 days (August, $11^{\text {th }}$ 2014) or 912.5 DD and 70 days (August, 15 2015) or 849.9 DD.

\section{Dry biomass accumulation}

Samples were collected at 14, 21, 28, 35, 42, 49, 56, 63, 70, and $77 \mathrm{DAE}$ for the 2014 growing season, and at 14, 21, 28, $35,42,49,56,63$, and 70 DAE for the 2015 growing season. In each experimental unit, plants contained in $1.0 \mathrm{~m}$ line were collected. In all collected plants, we separated them in leaves, stems, and pods, and the roots were discarded. These plant structures were dried at $60^{\circ} \mathrm{C}$ in an oven with forced air circulation until constant mass. We calculated the production of dry biomass of each plant structure and total (leaves + stems + pods).

\section{Normalized Difference Vegetation Index (NDVI)}

The NDVI was measured in the subplots at the same time of the biomass sampling, and the Holland Scientific Crop Circle ACS-470 Multi-Spectral Crop Canopy Sensor was used. Sensor readings were collected approximately from 0.7 to 0.9 $\mathrm{m}$ above dry bean canopy at a rate of 10 readings per second and walking in the same speed in the each subplot, and the average reflectance values were used to represent each subplot. Then, these reflectance values were used to calculate the vegetation index following the methods proposed by Rouse et al. (1974), Hong et al. (2007), Sui et al. (2008), Verhulst et al. (2009), Shaver et al. (2010), and Merotto et al. (2010).

\section{Leaf area index (LAI)}

LAI was measured in the subplots at the same time of the biomass sampling. The SunScan canopy analysis system (Delta-T Devices, Cambridge, UK) was used. LAI was indirectly measured with this SunScan sensor. Eight sub samples were randomly sampled in each experimental area, and the average index values were used to represent each subplot following the methods proposed by Oguntunde et al. (2012).

\section{Common bean harvesting}

Subplots were harvested by hand in the useful area, followed by mechanized stationary thresher. The harvested common bean grains were weighed and the yield was expressed as 130 $\mathrm{g} \mathrm{kg}^{-1}$.

\section{Statistical analyses}

We evaluated the dry biomass accumulated at the harvesting time in the 2014 and 2015 growing seasons. Then, an analysis of variance and $\mathrm{F}$ test were performed for all variables (stems, leaves, pods, and total). The analysis of variance was performed considering the effects of genotypes (main plots), $\mathrm{N}$ top-dressing fertilization (subplot), growing seasons (sub-subplots), and their interactions (Lima et al., 2005). In the significant data we performed the Tukey test at $\mathrm{p}<0.05$. Genotypes and $\mathrm{N}$ timing of top-dressing fertilization were considered fixed effects. Blocks, years, and interactions were considered random effects. Three error terms were considered in the analysis of the data; the first was associated with the $\mathrm{N}$ timing of top-dressing fertilization, the second, with the dry bean genotypes and interactions, and the third, with the growing seasons and interactions. These analyses 
were performed using SAS statistical software (SAS Institute, 1999). Data of total dry biomass accumulation during the dry bean life cycle were subjected to process of curve fitting to a simple logistic model with three parameters according to Pinheiro and Bates (2000).

\section{Conclusion}

From our results we could observe that the use of growth analysis, NDVI, and LAI was efficient to explain the plant development and the differences in grain yield by the super early genotypes of dry bean. Our results allow inferring that the CNFC 15875 super early genotype of dry bean had the higher grain yield $\left(2776 \mathrm{~kg} \mathrm{ha}^{-1}\right)$, which differed from the CNFC 15873 genotype $\left(2492 \mathrm{~kg} \mathrm{ha}^{-1}\right)$. The CNFC 15875 genotype is very promising and could be a very good option for farmers around the world. This genotype has a life cycle of 70-77 days, and could allow farmers to have two crops in the same growing season or three crops in irrigated areas. Therefore, by using this genotype, we could increase the food production without increasing new agricultural areas. Nitrogen application provided increases in the grain yield for all genotypes, differing from the control treatment (no $\mathrm{N}$ fertilization). However, the time of this $\mathrm{N}$ application will depend on the wish of the farmers, since the application at sowing, or at topdressing or split at sowing + at topdressing, did not have differences.

\section{Acknowledgment}

To the National Council for Scientific and Technological Development $(\mathrm{CNPq})$ for the financial support (Process 471812/2013-7).

\section{References}

Alvarez ACC, Alvarez RCF, Arf O, Pereira JCR (2005) Response of the bean plant to the application of rates and sources of side dressing nitrogen, in no-tillage system. Acta Sci Agron. 27:69-75.

Alvarez RCF, Crusciol CAC, Nascente AS (2012) Growth analysis and yield of traditional, intermediate and modern upland rice cultivars. Pesqu Agropecu Trop. 42:397-406.

Andrade CAB, Scapim CA, Braccini AL, Martorelli DT (2009) Yield, growth and dry matter partition in two common bean cultivars. Acta Sci Agron. 31:683-688.

Antoniazzi N, Deschamps C (2006) Growth analysis of two barley cultivars after elicitors and fungicides treatment. $\mathrm{Ci}$ Rural. 36:1065-1071.

Claessen MEC (1997) Manual for Methods of Soil Analysis, 2nd ed. Rio de Janeiro, Embrapa Solos.

Crusciol CAC, Mateus GP, Nascente AS, Martins PO, Borghi E, Pariz CM (2012) An Innovative Crop Forage Intercrop System: Early Cycle Soybean Cultivars and Palisadegrass. Agron J. 104:1085-1095.

Crusciol CAC, Nascente AS, Soratto RP, Rosolem CA (2013a) Upland rice growth and mineral nutrition as affected by cultivars and sulfur availability. Soil Sci Soc Am J. 77:328335.

Crusciol CAC, Nascente AS, Mateus GP, Borghi E, Leles EP, Santos NCB (2013b) Effect of Intercropping on Yields of Corn with Different Relative Maturities and Palisadegrass. Agron J. 105:89-94.

Doorenbos J and Pruitt WO (1976) Crop and water requirements. Rome, FAO. (FAO Irrigation and Drainage Paper n. 24).

Fageria NK (2014) Nitrogen management in crop production. CRC Press, Boca Raton.

Fageria NK, Baligar VC, Jones CA (2011) Growth and mineral nutrition of field crops. CRC Press, Boca Raton.
Falqueto AR, Cassoli D, Magalhães Júnior AM, Oliveira AC, Bacarini MA (2009) Growth and assimilates partitioning in rice cultivars difering in grain yield potencial. Bragantia. 68:453-461

FAOSTAT (2014) Production: Crops. Available at: <www.faostat.fao.org>. Accessed in September $29^{\text {th }}, 2014$.

Hong SD, Schepers JS, Francis DD, Shlemmer MR (2007) Comparison of ground-based remote sensors for evaluation of corn biomass affected by nitrogen stress. Commun Soil Sci Plant. 38:2209-2226.

Lima ER, Santiago AS, Araújo AP, Teixeira MG (2005) Effects of the size of sown seed on growth and yield of common bean cultivars of different seed sizes. Braz J Plant Physiol. 17:273281

Malavolta E (2006) Manual of mineral nutrition of plants Agronômica Ceres, São Paulo.

McMaster GS, Wilhelm WW (1997) Growing degree-days: one equation, two interpretations. Agr Forest Meteorol. 87:291300.

Merotto A, Bredemeier C, Vidal RA, Goulart ICGR, Bortoli ED, Anderson NL (2012) Reflectance indices as a diagnostic tool for weed control performed by multipurpose equipment in precision agriculture. Planta Daninha. 30:437-447.

Nascente AS, Kluthcouski J, Crusciol CAC, Cobucci T, Oliveira P (2012) Fertilization of common bean cultivars in tropical lowlands. Pesqu Agropecu Trop. 42:407-415.

Oguntunde PG, Abiodun BJ, Lischeid G, Merz C (2012) Modelling the impacts of reforestation on the projected hydroclimatology of Niger River Basin, West Africa, Ecohydrology. 7:163-176.

Pagani A, Mallarino AP (2012) Soil pH and crop grain yield as affected by the source and rate of lime. Soil Sci Soc Am J. 76:1877-1886.

Pinheiro JC, Bates DM (2000) Mixed-effects models in S and SPlus. Springer, New York.

Rosales-Serna R, Kohashi-Shibata J, Acosta-Gallegos JA, TrejoLópez C, Kelly JD (2004) Biomass distribution, maturity acceleration and yield in drought-stressed common bean cultivars. Field Crop Res. 85:203-211.

Rouse JW, Hass RH, Schell JA, Deering DW, Harlan JC (1974) Monitoring the vernal advancement of retrogradation (greenwave effect) of natural vegetation. NASA/GSFC, Type III, Final Report, Greenbelt, MD.

Santos LA, Soratto RP, Fernandes AM, Gonsales JR (2015) Growth, physiological indices and yield of common bean cultivars under different levels of fertilization. Rev Ceres. 62:107-116

SAS Institute (1999) Procedure guide for personal computers. Version 5. Cary.

Shaver TM, Khosla R, Westfall DG (2010) Evaluation of two ground-based active crop canopy sensors in maize: growth stage, row spacing, and sensor movement speed. Soil Sci Soc Am J. 74:2101-2108.

Sousa DMG, Lobato E (2003) Cerrado: soil correction and fertilization. Embrapa Cerrados, Planaltina, DF, Brazil.

Sui R, Thomasson JA, Hanks J (2008) Ground-based sensing system for weed mapping in cotton. Com Eletro Agri. 60:3138.

Valderrama M, Buzetti S, Bennett CG, Andreotti M, Arf O, Sá ME (2009) Sources and doses of nitrogen and phosporus in no till common beans. Pesqu Agropecu Trop. 39:191-196.

Verhulst N, Govaerts B, Sayre KD (2009) Using NDVI and soil quality analysis to assess influence of agronomic management on within-plot spatial variability and factors limiting production. Plant Soil. 317:41-59.

Vieira C, Paula Júnior TJ, Borém A (2006) Common Bean. UFV, Viçosa, MG, Brazil.

Wien HC, Altschuler SL, Wallace DH (1976) 14C-assimilate distribution in Phaseolus vulgaris L. during the reproductive period. J Am Soc Hortic Sci. 101:510-513. 